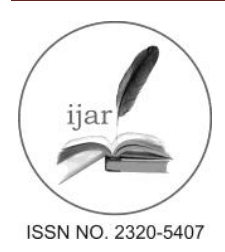

Journal homepage:http://www.journalijar.com

RESEARCH ARTICLE

\title{
ANALYSIS OF AGRO RESIDUE BURNING AND PRESENT SCENARIO IN KEY AREAS OF NORTHERN PLAINS IN INDIA
}

\author{
${ }^{* 1}$ A. Agarwal, ${ }^{1}$ E. Dintwa, ${ }^{2}$ P. Joshi \\ 1. Department of Mechanical Engineering, University of Botswana, Gaborone. \\ 2. Department of Environmental Engineering. Subharti University, India.
}

\begin{abstract}
Manuscript Info Abstract
Manuscript History:

Received: 14 January 2016

Final Accepted: 25 February 2016

Published Online: March 2016

Key words:

Air quality, River waterquality,

Crop residue; Air pollution;

Greenhouse gases, Aerosol.

*Corresponding Author

A. Agarwal

Email:

abhishek.agarwal@mopipi.ub.bw

According to MNRE report, India produces around 500 million tons (Mt) of harvest buildups every year. In India, crop blazing is a standard route for agriculturalists to ruin scraps after they reap deliver, for example, wheat, rice, sugarcane and so on. The smoldering of farming buildups, because of any reason causes a huge wellspring of artificially and radioactively critical follow gasses that are all that much hurtful for the climate. There are a few alternatives are accessible which can be polished, for example, treating the soil, era of vitality, generation of biofuel and reusing in soil to deal with the deposits in a gainful way. This study demonstrates the current state of this product smoldering buildups in northern piece of India, particularly in IndoGangetic zone\& its belongings, air and water quality level. Aerosol optical and radiative propertieshave been analyzed over the ground-based Aerosol Robotic Network (AERONET).We determine an expansion in AOD happened over the region amid the perception period, principally because of long-range transference of mist concentrates transmitted because of harvest deposit burning.
\end{abstract}

Copy Right, IJAR, 2016,All rights reserved

\section{Introduction}

India is based on agriculture. India is an agrarian country and generates a large quantity of agricultural wastes. India is an agrarian economy. A vast majority of land is used for farming and a wide range of crops are cultivated in its different agro-ecological regions. With a production of 93.9 million tons (Mt) of wheat, 104.6 Mt of rice, 21.6 Mt of maize, 20.7 Mt of millets, 357.7 Mt of sugarcane, 8.1 Mt of fibre crops (jute, mesta, cotton), 17.2 Mt of pulses and $30.0 \mathrm{Mt}$ of oilseeds crops, in the year 2011-12 (MoA, 2012), it is but natural that a huge volume of crop residues are produced both on-farm and off-farm. It is estimated that approximately 500-550 Mt of crop residues are produced per year in the country. These crop residues are used for animal feeding, soil mulching, bio manure making, thatching for rural homes and fuel for domestic and industrial use. Farming is the main occupation of three-quarters of the working population. Many peasants have farms that are too small for efficient agriculture. The main problem is the pressure of population on land sources. The soils are fertile and there is good rainfall over nearly all the region. Irrigation facilities bring water to about one-third of the cropped area. Wheat, rice, maize, millet, and pulses, such as beans, peas and lentils, are the major food crops.

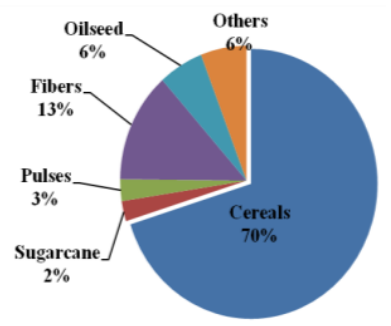

Uttar Pradesh is one of the country's major producers of sugar cane. Cotton, Fig.1-Crops residue generation in India oilseeds, jute, potatoes, and tobacco are other important cash crops. Uttar Pradesh (calculated from MNRE, 2009) is a major contributor to the national food grain stock. In 2013-14 state produced 50.05 million tons of food grain 
which is $18.90 \%$ country's total production. Partly this is due to the fertile regions of the Indo-Gangetic plain and partly owing to irrigation measures such as the canals and tube-wells. It has been the most common producer of food grains in India since the 1950s due to high-yielding varieties of seed, greater availability of fertilizers and increased use of irrigation. Western Uttar Pradesh is more advanced in terms of agriculture as compared to the other regions in the state. Majority of the state population depends upon farming activities. Wheat, rice, pulses, oil seeds and potatoes are the major agricultural products.

Sugarcane is the most important cash crop throughout the state. Uttar Pradesh is one of the most important state in India so far as horticulture is concerned. Mangoes are also produced in the state. Uttar Pradesh supports about 15\% of India's total livestock population. Of its livestock in 1961, $15 \%$ were cattle, $21 \%$ buffaloes, $13 \%$ goats and $8 \%$ other livestock. Between 1951 and 1956 there was an overall increase of 14\% in the livestock population. There are about $8,000 \mathrm{~km}^{2}$ of water area, including lakes, tanks, rivers, canals and streams. The fishing area in the state is over $2,000 \mathrm{~km}^{2}$ and there are more than 175 varieties of fish. North Indian Plain, extensive north-central section of the Indian subcontinent, stretching westward from the pooled delta of the Brahmaputra Rivervalley and the Ganges (Ganga) River to the Indus River valley.

In India, crop burning is a traditional way for farmers to decompose leftovers after they harvest produce such as wheat, rice and sugarcane. The Gangetic region covers the subcontinent's richest and most densely populated areas. The greater part of the plain is made up of alluvial soil, deposited by the three main rivers and their tributaries. In India, about 435.98 MMT of agro-residues are produced every year, out of which 313.62 MMT are surplus. These residues are either partially utilized or unutilized due to various constraints.

Table1- Ambient Air Quality in Uttar Pradesh January 2016 (Courtesy-U.P. pollution department)

\begin{tabular}{|l|l|l|l|l|l|}
\hline \multicolumn{5}{|c|}{ Ambient Air Quality in Uttar Pradesh -January 2016 } \\
\hline \multicolumn{2}{|c|}{ City } & \multicolumn{1}{|c|}{ Type } & \multicolumn{2}{c|}{ Microgram per meter cube } \\
\cline { 2 - 6 } & \multicolumn{2}{|c|}{ Place } & \multicolumn{1}{c|}{ PM10 $_{\mathbf{2}}$} \\
\hline Lucknow & Mahanagar & Residential & 263.8 & 12.59 & 37.27 \\
\hline Kanpur & Ramadevi & Commercial & 413.1 & 6.7 & 42.3 \\
\hline Agra & Bodla & Sensitive & 263.8 & 7.02 & 14.2 \\
\hline Ghaziabad & Sahibabad & Industrial & 402.7 & 16.34 & 40.65 \\
\hline Varanasi & BHU & Residential & 159.1 & 11.35 & 30.56 \\
\hline Noida & Regional & Residential & 156.0 & 9.0 & 27.0 \\
\hline Firozabad & CGDISN road & Sensitive & 300 & 10 & 38 \\
\hline Meerut & BegumBridge & Commercial & 180.3 & 7.4 & 61.7 \\
\hline Mathura & Regional & Sensitive & 148.1 & 10 & 24 \\
\hline Saharanpur & Clock Tower & Commercial & 190.7 & 13.02 & 26.72 \\
\hline
\end{tabular}

To cover the way for subsequent season for agriculture activity, the excess crop residues are burnt openly in the fields, unmindful of their ill effects on the environment. The study has been undertaken to evaluate the harshness of pollution through emission of greenhouse gases (GHGs) due to open field burning of agro-residues in northern India. Open field burning of surplus agro-residues in India results in the emission of GHG. Productions of CH4 and $\mathrm{N}_{2} \mathrm{O}$ in 1997-98 and 2006-07 have been which an increase of 8.88\% over a decade is. About three-fourths of GHG emissions from agro-residues burning were $\mathrm{CH} 4$ and the remaining one-fourth were $\mathrm{N} 2 \mathrm{O}$. Burning of wheat and paddy straws alone contributes to about $42 \%$ of GHGs.

These GHG emissions can be avoided once the agro-residues are employed for sustainable, cost-effective and environment- friendly options like power generation. JEnvironSci Eng. 2010 Oct;52(4):277-84.(Greenhouse gas emissions from open field burning of agricultural residues in India byMurali S, Shrivastava R, Saxena M). The population depends directly on this sector (Gupta, 1998; Lerche, 2011;Kalirajan and Singh, 2013). 
Table2-Quality of River Water in Uttar Pradesh area for January 2016 (Court.-U.P. pollution department)

\begin{tabular}{|c|c|c|c|c|c|}
\hline District & River & $\begin{array}{c}\text { Sample Collection } \\
\text { point }\end{array}$ & $\begin{array}{c}\text { D.O. } \\
\text { (Mg/lit) }\end{array}$ & $\begin{array}{l}\text { B.O.D. } \\
\text { (mg/lit) }\end{array}$ & $\begin{array}{l}\text { Total Coliforms } \\
(\text { MPN/100 ml)) }\end{array}$ \\
\hline Muzaffarnagar & Ganga & Shukratal & 7.90 & 1.8 & 130 \\
\hline Ghaziabad & Ganga & Garh & 9.72 & 2.06 & 1000 \\
\hline Kanpur & Ganga & Bitthor & 9.60 & 3.4 & 4700 \\
\hline Allahabad & Ganga & Downstream & 8.20 & 4.1 & 38000 \\
\hline Varanasi & Varuna & Rameshwar & 8.80 & 4.2 & 31000 \\
\hline Meerut & Kali & Kharkhauda & Nil & 58.0 & $240 \times 10^{3}$ \\
\hline Saharanpur & Hindon & downstream & Nil & 40.0 & 21000 \\
\hline Meerut & Hindon & Baghpat area & Nil & 45.0 & 170000 \\
\hline Jhansi & pond & Lakshmi Pond & 00 & 96 & 35000 \\
\hline Raibareilly & Lake & Samarpur & 5.10 & 4.7 & 8600 \\
\hline Mathura & Yamuna & kosighat & 4.80 & 8.2 & 70000 \\
\hline \multicolumn{2}{|c|}{ D.O.- Dissolved Oxygen } & \multicolumn{4}{|c|}{ B.O.D.- Biochemical oxygen demanded } \\
\hline
\end{tabular}

Although, the rice-wheat cropping system in the IGP is considered highly productive and it serves as a food basket for millions of people in that region, there are other concerns such as air pollution (Sidhu et al., 1998; Gupta et al., 2001; Saud et al., 2011). Every year, during the post-monsoon season (October - November), extensive agricultural (rice) crop-residue burning takes place in the Indo- Gangetic Plains (IGP), mainly in the northwestern Indian states of Punjab, Haryana and western Uttar Pradesh. [Sarkar et al., 2013]. The emissions from the burning locations travel thousands of kilometers downwind, covering the IGP from west to east. Sometimes, depending on the wind speed and direction, the Arabian Sea and Central-south India is also affected [Badarinath et al., 2009].

\section{Problem Identification \& Methodology-}

Ministry of New and Renewable Energy (MNRE 2009), (GOI) estimated that about 500 Mt of crop residue is generated every year. There is a large variability in crop residues generation and their use depending on the cropping intensity, productivity and crops grown in different states of India. The residue generation is highest in Uttar Pradesh (60 Mt). This burning includes forest fires, prescribed burning of savannas, and crop residue burning in fields. Typically, the biomass burning intensifies in late March, reaching a maximum in May. It represents a significant source of chemically and radioactively important trace gases and aerosols to the atmosphere thereby resulting in a large perturbation to global atmospheric chemistry (Crutzen and Andreae, 1990). The Agronomic crop residue burning add towards the emission of greenhouse gases as carbon di oxide, nitrogen di oxide, methane, air pollutants as carbon mono oxide, sulphor di oxide, NMHC, volatile organic compounds, particulates matter and smoke etc. Our study mainly focuses on changes in the meteorological parameters and the effects of crop-residue burning on them especially in northern region of India, known as Uttar Pradesh and neighboring areas.

In this aspect, we have taken air quality measure, River water quality measures, Modification of aerosol properties, Temperature range, and rain fall data during crop-residue burning seasons of different years and different places. In this respect, ground-based Lidar Network AERONET at Kanpur, Agra and satellite observations, weather statistics from various sources are utilized. Wind pattern have been studied by NCEP/NCER reanalysis. The open burning of agricultural residues results in emissions of trace gases like $\mathrm{CO} 2, \mathrm{CO}, \mathrm{CH} 4, \mathrm{~N} 2 \mathrm{O}$, NOx, NMHCs and aerosols (Prasad et al., 2000; Kant et al., 2000; Gupta et al.,2001; Badarinath et al.,2007, 2009; Sahai et al., 2010; Sarkar, 2007) which pose a health hazard to local inhabitants (Estrellan and Lino, 2010). Aerosols over India show a 
mixture of anthropogenic emissions, smoke from seasonal forest fires or crop residue burning, long range transported or even locally produced dust, and particles of marine origin during the summer monsoon.

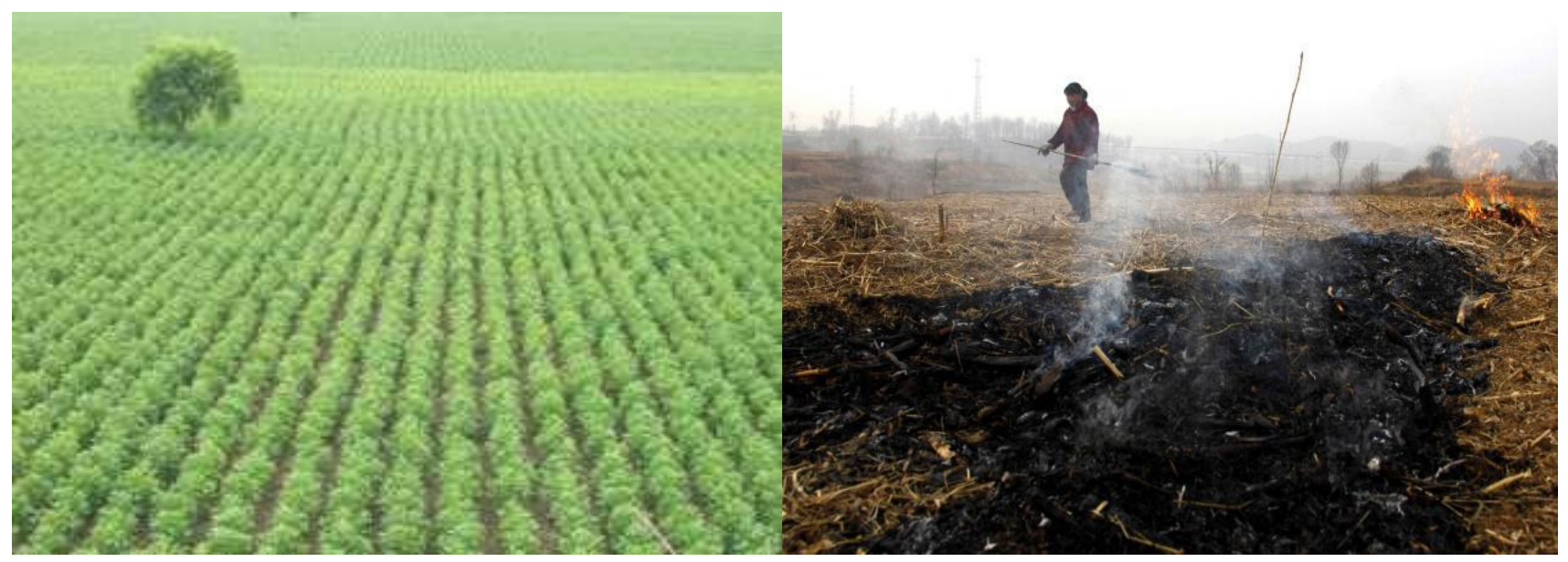

Fig.2- Crop Farms before and after crop burning

Emissions from open biomass burning over tropical Asia were evaluated during seven fire years from 2000 to 2006 by Chang et al. (2010). Venkataraman, (2006) have inventoried the emissions from open biomass burning including crop residues in India using Moderate Resolution Imaging Spectroradio meter (MODIS) active fire and land cover data approach. Badrinathet al. (2006) estimated the greenhouse gas (GHG) emissions from rice and wheat straw burning in Punjab during May and October 2005 and suggested that emissions from wheat crop residues in Punjab are relatively low compared to those from paddy fields. Sahaiet al. (2007) have measured the emission of trace gases and particulate species from burning of wheat straw in agricultural fields in Pant Nagar, Uttar Pradesh. Also, in China $37 \%$ of crop residues are directly combusted by farmers, $23 \%$ used for forage, $21 \%$ discarded or directly burnt in the field, $15 \%$ lost during collection, $4 \%$ for industry materials and $0.5 \%$ for biogas (Liu et al., 2008). Thus burning of crop residues in the field is a major problem in China as well. Incorporation of crop residues into soil or retention on the surface has several positive influences on physical, chemical and biological properties of soil.

\section{Analysis-}

The data on generation and surplus of crop residues in various states of India was obtained from Ministry of New and Renewable Energy (MNRE) Report 2009, Govt. of India (GOI). The data of pollution and water quality is taken from Uttar Pradesh pollution board. Experimental location, derived from the NCEP/NCAR re-analysis data have been examined with a view to investigating the contribution from additional sources through long-range transport and growth/accumulation processes. Tonged points to a report by urbanemissions.info, an independent research group, which says contribution of waste burning to PM2.5 pollution in Delhi stands at $31 \%$, as against $25 \%$ from the transport sector. On a global basis, forest burning is the major source of the fire emissions due to its high carbon density and burning of agricultural waste is the second major source, representing nearly $2020 \mathrm{Tg}$ (approx. 25\% of total biomass burned) (Crutzen and Andreae, 1990; Andreaeet al., 2001; Chang et al., 2010).

Table3- Crop wise Residue Generated in Mt per Year (Northern Part) MNRE

\begin{tabular}{|l|c|c|}
\hline \multicolumn{1}{|c|}{ States } & $\begin{array}{c}\text { Residue generation } \\
\text { (MNRE, 2009) }\end{array}$ & $\begin{array}{c}\text { Residue surplus } \\
\text { (MNRE, 2009) }\end{array}$ \\
\hline Haryana & 27.83 & 11.22 \\
\hline Punjab & 50.75 & 24.83 \\
\hline Tripura & 0.04 & 0.02 \\
\hline Uttarakhand & 2.86 & 0.63 \\
\hline Uttar Pradesh & 59.97 & 13.53 \\
\hline
\end{tabular}


Table4:Generation and surplus of crop residues (Source MNRE)

\begin{tabular}{|l|l|l|l|l|}
\hline State & Cereal Crops & Sugarcane & Oilseed Crops & Fibre Crops \\
\hline Uttar Pradesh & 72.02 & 41.13 & 2.49 & 0.04 \\
\hline Punjab & 45.68 & 1.76 & 0.08 & 9.32 \\
\hline Delhi & 0.17 & 0 & 0 & 0.00 \\
\hline Haryana & 24073 & 1.93 & 2.15 & 7.58 \\
\hline Uttrakhand & 2.40 & 2.11 & 0.03 & 0 \\
\hline
\end{tabular}

Industries and domestic cooking (biofuels), and heating come fourth and fifth, respectively. The farmers in Punjab, Haryana and Uttar Pradesh still follow the traditional method of crop burning to decompose leftovers after every agricultural Harvest. Images from NASA (National Aeronautics and Space Administration) show ow smoke due to crop burning is the biggest source of pollution. The mostly absorbing biomass-burning aerosols contribute significantly to the surface radiative forcing (-57.2 to-96.9 Wm-2) over the region and are responsible for large (43.0 to $86.5 \mathrm{Wm}-2$ ) atmospheric (lower and middle troposphere) heating [Sharma et al., 2012]. Internal or external mixing with other anthropogenic and natural aerosols forms the Atmospheric Brown Clouds (ABC), composed of soot, sulfates, organics, dust, etc. [Carmichael et al., 2009] that contribute to the Asian pollution outflow and haze [Lawrence and Lelieveld, 2010], which plays an important role in solar dimming, atmospheric heating and stability, monsoon circulation and hydrological cycle [Pinker et al., 2005; Ramanathan et al., 2005, 2007; Tripathi et al., 2007; Bollasina et al., 2008; Randles and Ramaswamy, 2008]. Furthermore, Gustafsson et al. [2009] observed that $\mathrm{BC}$ aerosols and associated dense brown clouds affect human health, cause pulmonary disease, bronchitis and asthma. The present study examines the impact of crop-residue burning on modification of aerosol properties, as well as the long range transport of smoke plumes, altitude characteristics and affected areas.

Therefore, column-averaged data from AERONET are used to characterize the variability's of these radiative relevant parameters during crop burning events. The single scattering albedo (SSA) is the ratio of scattering efficiency to total extinction efficiency and provides important information regarding the scattering and absorption properties of aerosols. Spectral variations in the SSA differ between dust and urban pollution, with the SSA tending to increase rapidly with increasing wavelength during dust events but to decrease during periods of increased urban pollution (Bergstrom et al., 2007; Dubovik et al., 2002). SSA consequently decreased with increasing wavelength. Singh et al. (2010) also found that the SSA decreased over Delhi with increasing wavelength during the winter, when local pollution is dominant, and a similar decrease in SSA with wavelength was reported by Zheng et al. (2008) in China. Kanpur SSA does not show much variation with increasing wavelength but decreases when crop burning effects occur.

\section{Issues and Government Actions-}

Because Smoke from such burning contains toxic substances, including fine particulate matter or PM 2.5, which is used to determine air quality. Air monitoring stations in Delhi \&documented PM 2.5 levels exceeding 300, a concentration the U.S. considers "hazardous" for health. Smoke from agricultural burning is one of two main contributors to the capital's worsening air pollution scenario - the other being carbon emissions from the millions of vehicles that ply Delhi's cramped roads. Pulling up Uttar Pradesh, Haryana, Punjab and Rajasthan for nonimplementation of its directions oncurbing open burning of crop residue, the environment ministry asked to launch an intense drive, including using satellite-based remote sensing technology, to monitor the practice. The burning of crop residue has already led to a thick layer of smog enveloping adjoining regions. The National Green Tribunal (NGT) in , asked Delhi and adjoining states to curb crop burning and imposed a fine on farmers indulging in such activities A study by Indian Institute of Tropical Meteorology says the relative contribution of the transport sector was highest in pushing PM2.5 pollution in Delhi-National Capital Territory in 2014. And it's not the only report that puts the blame squarely on vehicles for making region the worst place on the planet in terms of air quality. 
Table5: Crop calendar of Uttar Pradesh by NFSM (http://www.nfsm.gov.in/nfmis/RPT/CalenderReport.aspx)

\begin{tabular}{|c|c|c|c|c|c|}
\hline Sr. No. & Crop & Season & From & To & Period \\
\hline \multirow[t]{3}{*}{1} & \multirow{3}{*}{ Black gram/Urd } & Rabi & April (Beg) & April (End) & Sowing \\
\hline & & Rabi & June (Beg) & June (Mid) & Harvesting \\
\hline & & Summer & April (Beg) & June (End) & Sowing \\
\hline 2 & Chick Pea & Kharif & October (Mid) & October (Mid) & Sowing \\
\hline \multirow[t]{3}{*}{3} & \multirow{3}{*}{ Gram } & Rabi & October (Beg) & November (End) & Sowing \\
\hline & & Rabi & March (Beg) & April (End) & Harvesting \\
\hline & & Rabi & April (Beg) & June (End) & Harvesting \\
\hline \multirow[t]{4}{*}{4} & \multirow{3}{*}{ Green gram } & Kharif & September (Beg) & December (Beg) & Sowing \\
\hline & & Kharif & October (Mid) & October (Mid) & Sowing \\
\hline & & Rabi & April (Beg) & June (End) & Harvesting \\
\hline & Maize & Kharif & June (Beg) & October (Beg) & Sowing \\
\hline \multirow[t]{2}{*}{6} & \multirow{2}{*}{ Masur/Lentil } & Rabi & October (Beg) & November (End) & Sowing \\
\hline & & Rabi & March (Beg) & March (End) & Harvesting \\
\hline \multirow[t]{3}{*}{7} & \multirow{3}{*}{ Peas } & Rabi & April (Beg) & July (Beg) & Sowing \\
\hline & & Rabi & April (Beg) & June (End) & Harvesting \\
\hline & & Rabi & April (Beg) & June (End) & Harvesting \\
\hline \multirow[t]{4}{*}{8} & \multirow{4}{*}{ Red gram/Arhar } & Kharif & October (Mid) & April (Beg) & Sowing \\
\hline & & Kharif & January (Beg) & July (End) & Sowing \\
\hline & & Kharif & January (Beg) & January (Mid) & Harvesting \\
\hline & & Kharif & March (Beg) & April (Mid) & Harvesting \\
\hline \multirow[t]{4}{*}{9} & \multirow{4}{*}{ Rice/Paddy } & Kharif & July (Beg) & October (Beg) & Sowing \\
\hline & & Kharif & June (Beg) & August (End) & Sowing \\
\hline & & Kharif & October (Beg) & December (Mid) & Harvesting \\
\hline & & Kharif & October (Beg) & December (Mid) & Harvesting \\
\hline \multirow[t]{2}{*}{10} & \multirow{2}{*}{ Wheat } & Rabi & October (Beg) & January (Mid) & Sowing \\
\hline & & Rabi & January (Beg) & December (Beg) & Sowing \\
\hline
\end{tabular}




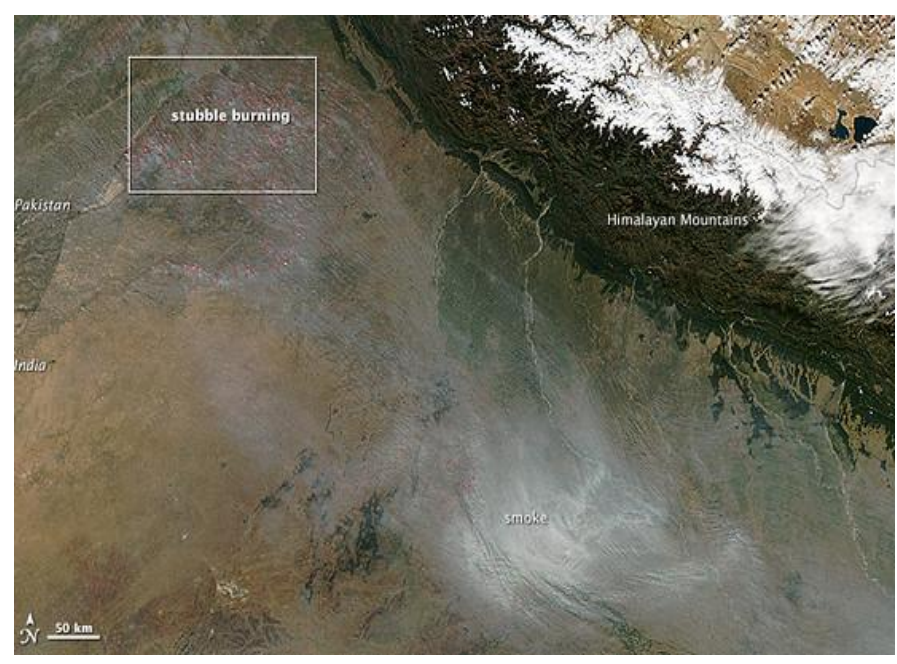

Fig.3- Nov. 12, 2013 image, taken from NASA's Aqua satellite, shows crop burning or "stubble burning" in northern India. NASA Earth Observatory

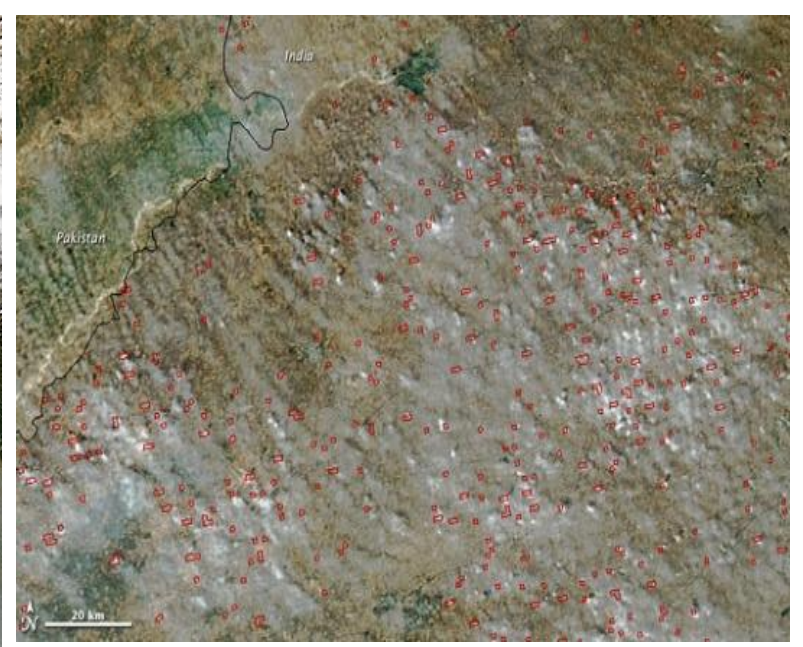

Fig.4- Nov. 12, 2013 image, taken from NASA's Aqua satellite, is a close-up of active crop burning in northern India. NASA Earth Observatory

The variation in AOD at a wavelength of 500nm and <alpha $>(440-870 \mathrm{~nm})$ during January 2014 is shown in figures. <alpha> is determined from the spectral dependence of the measured optical depth as suggested by Angström(1961). <alpha> is a good indicator of aerosol particle size. Single scattering albedo (SSA) is one of the key quantity for the determination of the aerosol radiative forcing effects. Together with the aerosol optical depth (AOD) this quantities determine the aerosol radiative forcing effects.

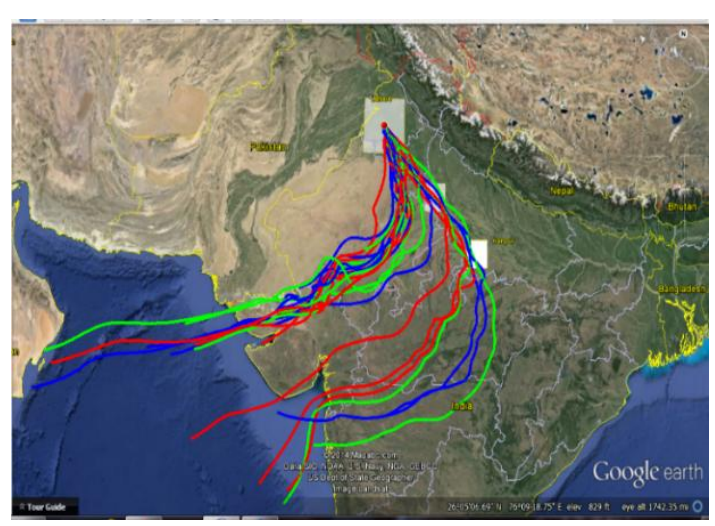

Fig.5- Average wind flow in Indo-Gangetic plain January

Time Series, Area-Averaged of Aerosol Optical Depth $550 \mathrm{~nm}$ (Dark Target) daily 1 deg. [MODIS-Terra MOD08 D3 v051] over 2014-11-01 - 2014-11-30, Region 74.707E, 28.0371N, 78.3984E, 31.2891

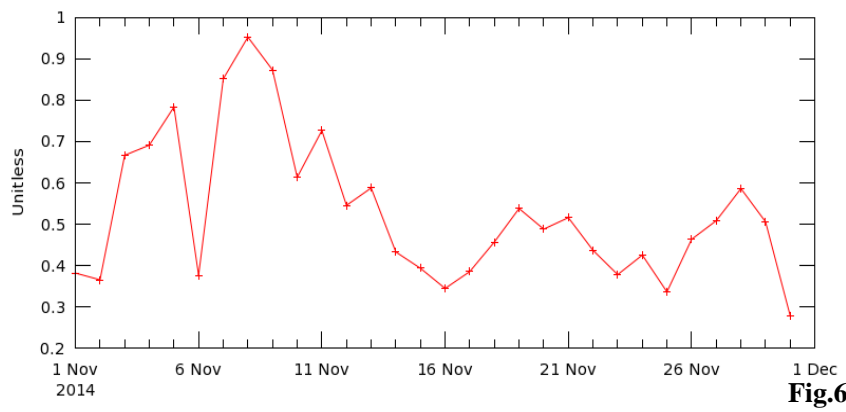

Aerosol optical depth at $500 \mathrm{~nm}$ (taua500), Angstrom exponent (a440-870)

\begin{tabular}{|c|c|c|c|c|c|c|c|}
\hline $\begin{array}{c}\mathbf{2 0 1 3} \\
\text { Averages } \\
\text { of }\end{array}$ & tau $_{\mathbf{a 5 0 0}}$ & sigma & $\begin{array}{c}\text { alpha }_{\mathbf{4 4 0}-} \\
\mathbf{8 7 0}\end{array}$ & sigma & PW & sigma & N \\
\hline JAN & 0.87 & 0.31 & 1.2 & 0.17 & 0.99 & 0.54 & 24 \\
\hline FEB & 0.57 & 0.32 & 1.3 & 0.17 & 1.38 & 0.53 & 20 \\
\hline MAR & 0.33 & 0.13 & 1.21 & 0.26 & 1.32 & 0.48 & 17 \\
\hline APR & 0.62 & 0.15 & 0.77 & 0.32 & 2.44 & 0.54 & 18 \\
\hline MAY & 0.71 & 0.17 & 0.64 & 0.2 & 2.45 & 0.71 & 31 \\
\hline JUN & 0.98 & 0.4 & 1.06 & 0.26 & 5.11 & 0.7 & 20 \\
\hline JUL & 0.57 & 0.18 & 1.18 & 0.32 & 5.81 & 0.32 & 9 \\
\hline AUG & 0.39 & 0.15 & 1.34 & 0.24 & 5.28 & 0.28 & 8 \\
\hline SEP & 0.61 & 0.35 & 1.11 & 0.33 & 4.55 & 0.57 & 28 \\
\hline OCT & 0.74 & 0.33 & 1.32 & 0.12 & 2.75 & 0.85 & 22 \\
\hline NOV & 0.95 & 0.35 & 1.39 & 0.11 & 1.31 & 0.45 & 27 \\
\hline DEC & 0.85 & 0.43 & 1.3 & 0.12 & 1.25 & 0.37 & 28 \\
\hline
\end{tabular}

Table6 -Kanpur (N 26³0', E 80¹3', Alt 123 m)- 2013

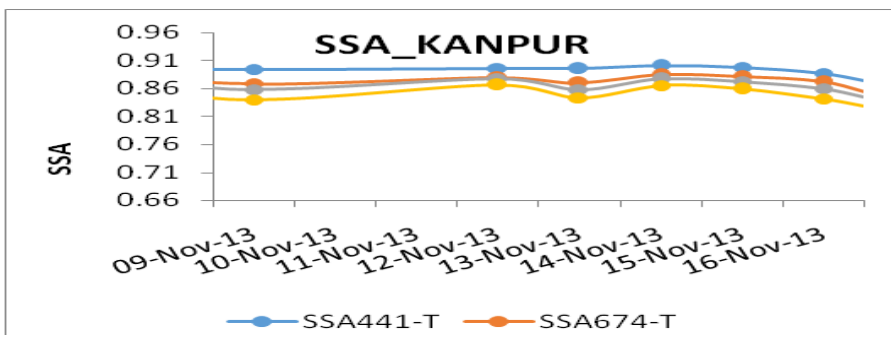

Fig.6- Aerosol optical depth 500nm (MODIS) during 1 to 30/11/14 O-T

Fig.7- SSA at Kanpur during Nov 13 
Table7 -Kanpur (N 26³0', E 80²13', Alt 123 m )- 2013 Quality Assured Data 2014

\begin{tabular}{|c|c|c|c|c|c|c|c|}
\hline $\begin{array}{c}2014 \\
\text { of } \\
\text { of }\end{array}$ & tau $_{\mathbf{a 5 0 0}}$ & sigma & alpha $_{\mathbf{4 4 0 - 8 7 0}}$ & sigma & PW & sigma & N \\
\hline JAN & 1.01 & 0.44 & 1.05 & 0.21 & 1.18 & 0.48 & 16 \\
\hline FEB & 0.62 & 0.24 & 1.26 & 0.18 & 1.49 & 0.6 & 23 \\
\hline MAR & 0.44 & 0.11 & 1.01 & 0.22 & 1.88 & 0.47 & 28 \\
\hline APR & 0.43 & 0.14 & 0.73 & 0.17 & 1.76 & 0.45 & 23 \\
\hline MAY & 0.58 & 0.18 & 0.78 & 0.22 & 2.77 & 0.64 & 23 \\
\hline
\end{tabular}

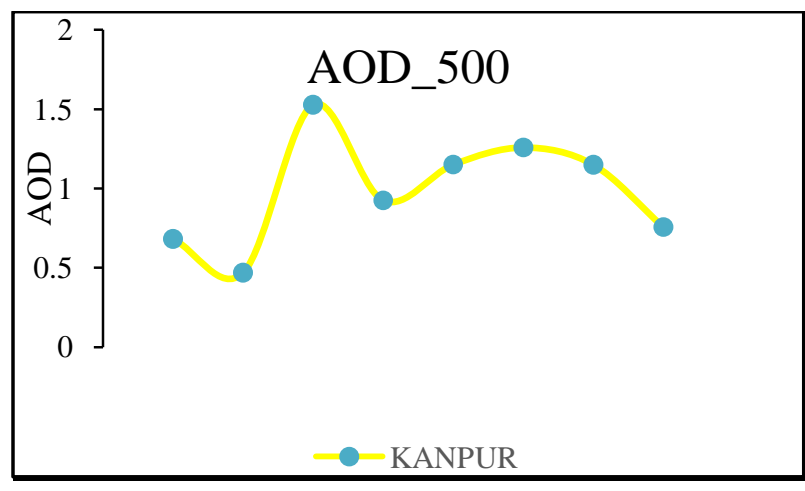

Fig.-8 AOD at Kanpur area at 500nm

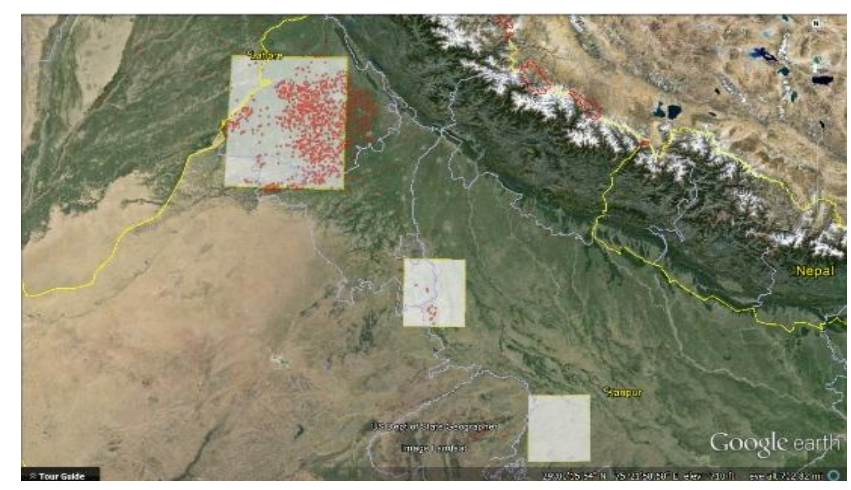

Fig.9- Satellite map of crop burning

\section{Conclusion: Need for Multi-point Strategies-}

Crop deposit burning amid during the end in 2013 and beginning months in 2014 period fundamentally influences barometrical synthesis around the subcontinent. We have found that the progressions in environmental structure are even detectible by satellite remote sensors. Aftereffects of the multi-satellite information examinations demonstrated that an expansion in AOD500 happened over the Kanpur predominantly because of long-range transport of vaporizers discharged because of product buildup copying in the IGP area. The SSA of Kanpur abatements with the expanding wavelength speaks to the impacts crop smoldering amid the period. Blazing of horticultural buildups, speak to a huge wellspring of synthetically and radioactively imperative follow gasses and vaporizers, for example, $\mathrm{CH} 4, \mathrm{CO}, \mathrm{N} 2 \mathrm{O}, \mathrm{NOX}$ and different hydrocarbons to the air influencing the environmental piece. This prompts a territorial increment in the levels of mist concentrates, corrosive statement, increment in tropospheric ozone and exhaustion of the stratospheric ozone layer. It additionally radiates expansive measure of particulates that are made out of wide assortment of natural and inorganic species. With clashing reports and studies on the real wellsprings of air contamination in entire Uttar Pradesh and neighboring ranges. It's an ideal opportunity to take an allencompassing approach as opposed to survey the issue through one crystal. Whether its rising discharge from vehicles, or surging smoke from copying horticultural waste or broad vicinity of dust because of development exercises or utilization of biofuels for cooking, all are doing their bit to make air in the locale more noxious.

The burning of yield buildup and biomass in rural fields in north India escalates the issue of air contamination. States with Uttar Pradesh representing 23\%, trailed by Punjab (22\%) and Haryana (9\%). As indicated by IPCC, the product deposit blazed in 8-9 was $22.38 \mathrm{Mt} / \mathrm{year}$. The study demonstrates the district savvy evaluations of air toxins radiated likewise from field blazing of product buildups in northern piece of India. It is found that the gathering of grain buildups is highest in Uttar Pradesh (53 Mt) overviewed by Punjab (44 Mt) and West Bengal (33 Mt). The offer of surplus smoldering to PM10, at 17\%, is again higher than that of the transportation division (14\%).

Taking into account the study we can say that, the deposits can be put to different uses and is conceivable if buildup is gathered and oversaw appropriately. With higher buildup levels, nonetheless, vanishing is decreased and more water is kept up close to the surface, which supports the development of feeder roots close to the surface where the supplements are concentrated. On the other hand, residues can be used in wellspring of energy as bio fuel, Biomethanization and ethanol generation, Production of Bio oil, Composting of deposits for fertilizer and so on. Limit 
working through instructing furthermore through preparing of ranchers to utilize buildup protection hones and encourage innovation exchange will be useful for this. The utilization of buildups/squanders to include natural matter in a proper structure ought to be a necessary part of the creation framework. There is a need to make mindfulness among the cultivating groups about the significance of harvest buildups. Supervision of yield buildups in preservation agribusiness is basic for long haul maintainability of Indian horticulture. Therefore, Burning of buildups must be halted or other new systems ought to be utilized to down its harness.

\section{Reference-}

1. IPCC (Intergovernmental Panel on Climate Change) (2000).Good Practice Guidance and Uncertainty Management in National Greenhouse Gas Inventories (Cambridge University Press, New York).

2. IPCC (Intergovernmental Panel on Climate Change) (2006). Guidelines for National Greenhouse Gas Inventories (IGES, Japan) (www.ipcc.ch).

3. Bandyopadhyay, S.K., Pathak, H., Kalra, N., Aggarwal,P.K, Kaur, R., Joshi, H.C., Choudhary, R. and Roetter,R.P. (2001). Yield Estimation and Agro-Technical Description of Production Systems.

4. Mittal, S.K., Susheel, K., Singh, N., Agarwal, R., Awasthi,A. and Gupta, P.K. (2009). Ambient Air Quality duringWheat and Rice Crop Stubble Burning Episodes inPatiala. Atmos. Environ. 43: 238-244.

5. Ministry of New and Renewable Energy Resources (2009).www.mnre.gov.in/relatedlinks/.

6. Venkataraman, C., Habib, G., Kadamba, D., Shrivastava,M., Leon, J.F., Crouzille, B., Boucher, O. and Streets,D.G. (2006). Emissions from Open Biomass Burning in India: Integrating the Inventory Approach with HigherSolution Moderate Resolution Imaging Spectroradiometer(MODIS) Active Fire and Land Count Data. GlobalBiogeochem. Cycles 20: GB2013-20.

7. Yang, S., He, H., Lu, S., Chen, D. and Zhu, J. (2008).Quantification of Crop Residue Burning in the Field and its Influence on Ambient Air Quality in Suqian, China. Atmos. Environ. 42: 1961-1969.

8. Zhang, H., Hu, D., Chen, J., Ye, X., Wang, S.X., Hao, J.,Wang, L., Zhang, R. and Zhisheng, A., (2011). Particle Size Distribution and Polycyclic Aromatic HydrocarbonsEmissions from Agricultural Crop Residue Burning.Environ. Sci. Technol. 45: 5477-5482.

9. Crop Residue Management with conservation agriculture IARI 2012:http://www.iari.res.in/files/Important_Publications-2012-13.pdf

10. Liu H, Jiang GM, Zhuang HY, Wang KJ (2008) Distribution, utilization structure and potential of biomass resources in rural China: With special references of crop residues. Renewable and Sustainable Energy Reviews 12:1402-1418.

11. Niveta Jain*, Arti Bhatia, Himanshu Pathak, Emission of Air Pollutants from Crop Residue Burning in India in Aerosol and Air Quality Research, 14: 422-430, 2014.

12. Pathak H, Bhatia A and Jain N (2010) Inventory of greenhouse gas emission from agriculture. Report submitted to Ministry of Environment and Forests, Govt. of India.

13. Derpsch R and Friedrich T (2010) Global overview of conservation agriculture adoption. In Conservation Agriculture: Innovations for Improving Efficiency, Equity and Environment, (PK Joshi et al. eds), National Academy of Agricultural Sciences, New Delhi India, p 727-744.

14. http://www.nfsm.gov.in/nfmis/RPT/CalenderReport.aspx

15. MoA (Ministry of Agriculture) (2012) Govt. of India, New Delhi.www.eands.dacnet.nic.in.

16. Derpsch R and Friedrich $\mathrm{T}$ (2010) Global overview of conservation agriculture adoption. In: Conservation Agriculture: Innovations for Improving Efficiency, Equity and Environment (Eds. PK Joshi et al.), National Academy of Agricultural Sciences, New Delhi, India, pp 727-744.

17. Shi Y, Zhang J, ReidJS,Hyer EJ, Eck TF, Holben BN, Kahn RA (2011), A critical examination of spatial biases between MODIS and MISR aerosol products - application for potential AERONET deployment, Atmos. Measur. Techn., 4, 2823-2836.

18. Zheng Y, Liu J, Wu R, Li Z, Wang B, Tamio T(2008). Seasonal statistical characteristics of aerosol optical properties at a site near dust region in China. Journal of Geophysical Research 113 (D16205). doi:10.1029/2007JD009384.

19. Tripathi SN, Srivastva AK, DeyS, Satheesh SK, Krishnamoorthy K (2007), The vertical profile of atmospheric heating rate of black carbon aerosols at Kanpur in northern India, Atmos. Environ., 41, 6909-6915.

20. Kant Y, Ghosh AB, Sharma MC, Gupta PK, Prasad VK, Badarinath KVS, MitraAP(2000). Studies on aerosol optical depth in biomass burning areas using satellite and ground-based observations. Infrared Phys. Technol. 41 (1), 21-28.

21. Solomon, S., Qin, D., Manning, M., Chen, Z., Marquis, M., Averyt, K. B., Tignor, M., and Miller, H. L. (Eds.): Contribution of Working Group I to the Fourth Assessment Report of the Intergovernmental Panel on Climate Change, Cambridge University Press, 996 pp., 2007. 
22. Ramanathan V, Chung C, Kim D, Bettge T, Buja L, Kiehl JT, Washington WM, FuQ,Sikka DR, Wild M (2005), Atmospheric brown clouds: Impacts on South Asian climate and hydrological cycle, PNAS, 102, 5326 - 5333, doi:10.1073/pnas.0500656102.

23. Badarinath KVS, Kharol SK, Sharma AR, Prasad VK(2009) Analysis of aerosol and carbon monoxide characteristics over Arabian Sea during crop residue burning period in the Indo-Gangetic Plains using multi-satellite remote sensing datasets. J.Atmos. Solar-Terrest. Phys. 71 (12), 1267-1276.

\section{Acknowledgement-}

We are also thankful to MODIS and NASA(http://modis.gsfc.nasa.gov) for providing satellite data. 